\author{
키토산 첨가 양념돈육의 저장성 및 품질 개선에 관한 연구 \\ 윤선경* . 최정수*** . 박선미* . 안동현** \\ 부경대학교 식품생명공학부*. =산식품연구소**, 경남정보대학 식품과학계열***
}

\title{
Studies on the Improvement of Shelf-life and Quality of Vacuum- Packaged Seasoned Pork Meat by Added Chitosan During Storage
}

\author{
S. K. Youn*, J. S. Choi***, S. M. Park* and D. H. Ahn** \\ Faculty of Food Science \& Biotechnology*, Institute of Sea Food Science**, \\ Pukyong National University, Pusan 608-737, Korea \\ Food Science Subdivision, Kyungnam College \& Technology, Pusan 617-701, Korea***
}

\begin{abstract}
This study was carried out to investigate the effect of chitosan on shelf-life and quality of vaccum-packaged seasoned pork. Chitosan was used $120 \mathrm{kDa}$ and various concentration such as $0.05 \sim 1.0 \%$. The total bacterial counts, $\mathrm{pH}$, oxidation of lipid, surface color and water holding capacity of the sample were determined during storage periods. The total bacterial counts of seasoned pork without chitosan were increased the latter period of storage, but that of seasoned pork with chitosan was decreased such as inhibition of bacterial growth effectively. Effect on shelf-life of seasoned porks when added $0.10 \%, 0.50 \%$ and $1.00 \%$ of chitosan, respectively were maintained pretty well during 10 days of storage. Content of TBARS in seasoned pork without chitosan was increased than that of seasoned pork with chitosan during period of storage. And also effect of self-life and inhibition of lipid oxidation were increased with following concentration of chitosan. The variation of $\mathrm{pH}$ was low and stable in seasoned pork with chitosan during periods of storage. The change of color such as lightness $\left(\mathrm{L}^{*}\right)$, redness $\left(\mathrm{a}^{*}\right)$, yellowness $\left(\mathrm{b}^{*}\right)$ in seasoned pork with chitosan was detected higher than that seasoned pork without chitosan. Water holding capacity of seasoned pork with low in the early period of storage. These colors and water holding capacity were very stable untill 10 days of storage.

(Key words : Chitosan, Seasoned pork, Vaccum-packaging, Shelf-life, Antioxidation)
\end{abstract}

$\begin{array}{ccl}\text { I 서 론 } & \begin{array}{l}\text { 는 식품의 섭취로 질병의 방지와 회복 및 노화 } \\ \text { 억제 등의 기능들이 대두되어 건강 지향적인 }\end{array} \\ \text { 경제적인 발전과 동서간 문화교류에 의해 식품개발이 활발히 진행되어 기능성 식품 등 } \\ \text { 생활수준의 향상과 사회구조의 급격한 변화 } & \text { 이 상품화되고 있다. 특히, 축육 식품 가운데 } \\ \text { 로 인하여 식생활 패턴도 크게 변하여 식육 } & \text { 돼지고기는 쇠고기에 비해 값이 저렴하고 영 } \\ \text { 류의 소비가 점차 증가하였으며, 양 보다는 양 면에서도 손색이 없어 대중들로부터 널리 } \\ \text { 질을 중요시 하고 있다(Cho 등, 2002). 최근에 애용되는 육류이다(Choi와 Lee, 2002). 1인당 연 }\end{array}$

Corresponding author : Dong-Hyun Ahn, Faculty of Food Science and Biotechnology/Institute of Seafood Science, Pukyong National University, Daeyean 3-dong, Nam-gu, Pusan 608-737, Korea. Tel : 82-51-620-6429, Fax : 82-51-622-9248, E-mail : dhahn@pknu.ac.kr 
간 돼지고기 소비량은 90 년도에 $11.8 \mathrm{~kg}$ 에서 99년도에는 $16.1 \mathrm{~kg}, 2000$ 년도에는 $16.5 \mathrm{~kg}$ 으로 증가하였고, 이러한 증가 추세는 앞으로도 계 속될 전망이다(Statistical yearbook of agricultural and forestry industries. MAF, 2001). 돼지고 기의 소비가 증가하면서 전통적인 돼지고기 가 공품인 양념육의 시장규모 또한 급속히 성장하 고 있다. 국내 관계 법규에 따른 양념육에 대 한 정의를 살펴보면 '식육에 식염, 조미료, 향 신료 등으로 양념하고 냉장 또는 냉동한 것으 로 육 함량 $60 \%$ 이상의 것을 말한다(Official Book for Food, KFDA, 2002)로 되어 있다. 또한 양념육에 적용되는 성분의 규격은 성상으로 고 유의 색택을 가지고 이미, 이취가 없고, 아질산 이온은 $70 \mathrm{ppm}$ 이하이며 보존료로서 소르빈산과 소르빈산 칼륨이 $2 \mathrm{~g} / \mathrm{kg}$ 이하여야 한다고 규정되 어 있다(Official Book for Food, KFDA, 2002). 양 념육에 사용되는 양념류는 통상 육취의 제거뿐 만 아니라 연육작용으로 소화흡수를 도와주고 (Moon 등, 1991), 양념에 첨가되는 소금은 풍미 를 향상시키고 육의 보수성을 증진시킴으로 조 직감을 부여함과 동시에 미생물의 생육을 억제 하는 등 다양한 역할을 하고 있다(Oh, 1986).

이러한 양념육은 아직까지 양념재료나 제조 법이 체계화되어 있지 않으며 가정이나 일부 음식점에서만 조리·판매되고 있을 뿐 아니라 유통기한의 설정과 이의 연장을 위한 기술적 체계가 제대로 확립되어 있지 않아, 저장과 유 통 과정 중 많은 문제점들이 나타나고 있다 (Choi 와 Lee, 2002).

한편, 키틴은 게, 새우 등 갑각류의 껍질이나 곤충의 표피, 버섯, 균류의 세포벽 등에 널리 분포되어 있는 천연고분자 물질인 키틴을 탈아 세틸화(Skjak 등, 1989; Goosen, 1997)하여 얻어 진다. 키토산은 많은 유리 양이온을 지닐 수 있기 때문에 여러 생리 활성과 함께 항균 작용 등을 가지는 것으로 알려져 있는데 분자량에 따라 항균성이 차이가 있는 것으로 알려져 있 다(Yun 등, 1999, Youn 등, 2000). 이러한 키토 산을 각종 식품에 적용 했을 때 뛰어난 보존제 로서의 효과를 나타낸 연구들이 많이 보고되고 있다. 그 예로 콩이나 옥수수와 같은 식물의
종자에 코팅함으로써 보존성을 증진한 연구 (Donald와 Mirocha, 1977; Hadwiger 등, 1984)와 달걀의 표면 코팅에 따른 저장성 및 품질의 향 상(Lee 등, 1996), 그리고 생새우나 생굴에 키 토산을 처리함으로써 저장성을 향상(Simpson 등, 1997; Chen 등, 1998)시킨 연구 등이 보고 되고 있다. 특히 식품 분야에서 키토산을 사용 하였을 때, 김치 $(\mathrm{Kim}$ 등, 1995; No 등, 1995; Son 등, 1996; Hur 등, 1997), 두부(Chun 등, 1997) 등의 저장성 향상, 축육 소시지의 보존성 개선(Youn 등, 2000) 및 항산화 효과(Youn 등, 2001) 등의 연구가 보고되고 있어 고부가가치 기능성 식품 첨가물로서 키토산의 이용 가능성 이 점차 확대되고 있다.

따라서 본 연구에서는 양념 돈육의 저장성을 연장함과 동시에 기능성을 가진 양념돈육을 개 발하기 위해 천연보존제로 널리 이용되고 있는 키토산을 양념돈육에 첨가하여 저장성 증진 및 품질 향상 효과에 대해 알아보았다.

\section{프래료 및 방법}

\section{1. 실험 재료}

본 실험에서 사용된 원료 돈육은 당일 도살 된 돼지의 갈비부위를 구입하여 두께 $0.3 \mathrm{~cm}$ 로 자른 후 사용하였다. 양념 용액은 Table 1 과 같 이 돈육의 중량 $4 \mathrm{~kg}$ 에 대해 양념재료를 혼합 하여 제조한 다음, 양념용액이 잘 스며들도록 원료 돈육과 잘 혼합하여 준비하였다. 또한 키 토산은 분자량 약 $120 \mathrm{kDa}$ 의 것을 $0.3 \%$ 젖산 용액 $(\mathrm{pH}$ 2.52)에 용해한 후 $\mathrm{pH}$ 를 5.5 로 조절하 여 원료돈육에 대한 최종 농도로 0.05 에서 1.0 $\%$ 까지 첨가하였다. 각각 처리한 양념 돈육 은 진공포장지(나일론 $+\mathrm{PE}$ 로 진공 포장하여 각각 $4{ }^{\circ} \mathrm{C}$ 에 저장하였다.

\section{2. 생균수 측정}

제조한 양념돈육을 $4{ }^{\circ} \mathrm{C}$ 에 각각 저장하면서 경시적으로 검체를 채취하여 생균수를 측정하였 다. 생균수의 측정은 각 시료 $1 \mathrm{~g}$ 을 무균적으로 
Table 1. Ingredients for preparation of seasoned pork meat

\begin{tabular}{lr}
\hline \multicolumn{1}{c}{ Ingredients } & (\%) \\
\hline Pork meat & 58.0 \\
Soy sauce & 6.0 \\
Starch syrup & 2.0 \\
Sugar & 3.0 \\
Water & 18.0 \\
Monosodium glutamate & 0.6 \\
Soda pop & 3.7 \\
Caramel sauce & 0.6 \\
Soybean paste & 1.0 \\
Liquorice & 0.4 \\
Coffee & 0.3 \\
Wine & 1.7 \\
Ginger extract & 0.7 \\
Onion extract & 1.3 \\
Garlic extract & 2.0 \\
Pepper & 0.1 \\
Powdered red pepper & 0.3 \\
Powdered sesame mixed with salt & 0.1 \\
Sesame oil & 0.1 \\
Bean oil & 0.1 \\
\hline Total & $100(\%)$ \\
\hline
\end{tabular}

채취하여 멸균한 phosphate buffered saline용액 (pH 7.4) $9 \mathrm{ml}$ 를 넣어 homogenize(AM-7, ace homogenizer, Nihonseiki, Japan)한 다음, 10 배 희석법으로 희석하여 nutrient agar에 도말하 고, $37^{\circ} \mathrm{C}$ 에서 24 시간 배양 후 colony수를 측 정하였다.

\section{3. 색의 측정}

각 시료를 $2 \times 2 \times 1.5 \mathrm{~cm}$ 의 크기로 절단하여 색차계(JC801, Color techno system Co., Japan) 를 사용하여 $\mathrm{L}^{*}$ (명도), $\mathrm{a}$ *(적색도), $\mathrm{b} *$ (황색도)값 으로 나타내었다. 이 때 사용된 표준백판의 값 은 $\mathrm{L}^{*}=93.73, \mathrm{a}^{*}=-0.12, \mathrm{~b}=0.11$ 였다.

\section{4. 산화도의 측정}

양념 돈육을 약 $5 \mathrm{~g}$ 분쇄한 다음 3 배의 초순수 를 첨가하여 $3,000 \mathrm{rpm}$ 에서 1 분간 균질화(AM-7, ace homogenizer, Nihonseiki, Japan)한 다음 glass wool에서 여과하였다. 이 여액 $0.5 \mathrm{ml}$ 에 $7.2 \%$ BHT $50 \mu \mathrm{l}$, TBA/TCA용액 $2 \mathrm{ml}$, 초순수 $0.5 \mathrm{ml}$ 를 첨가하여 완전히 혼합한 후, 끓는 물에서 15 분간 가열한 다음 냉각하여 $4{ }^{\circ} \mathrm{C}, 2000 \times \mathrm{g}$ 로 10 분간 원심분리기(Union 32R, Hanil, Korea) 로 원심분리 하였다. 상징액을 $531 \mathrm{~nm}$ 에서 흡 광도를 측정하여 아래의 식에 의하여 TBARS (Thiobarbituric Acid Reactive Substances)의 함 량, 즉 돈육의 $\mathrm{kg}$ 당 malonaldehyde 양 $(\mathrm{mg})$ 으 로 나타내었다.

$\mathrm{TBARS}=\frac{\text { 시험구의 흡광도 값 }- \text { sample의 흡광도 값 }}{0.6742} \times 1.6$

\section{5. 보수력의 측정}

양념 돈육을 $20 \mathrm{~g}$ 채취하여 분쇄 후 보수력 측정용 원심관에 기포가 없도록 채우고 $70{ }^{\circ} \mathrm{C}$ 에서 30 분간 가열 처리하였다. 가열된 원심관 을 실온에서 10 분간 방냉하여, $230 \times \mathrm{g}$ 에서 10 분 동안 원심분리하고 분리된 액즙량을 측 정하였다(Wierbick 등, 1975).

수분손실 $(\%)=\frac{\text { 분리된 액즙량 }(\mathrm{ml}) \times 0.951}{\text { 시료 총수분 함량 }(\mathrm{ml})} \times 100$

보수력 $(\%)=100-\%$ 수분 손실

6. $\mathrm{pH}$ 의 측정

각 양념돈육 $5 \mathrm{~g}$ 과 증류수 $50 \mathrm{ml}$ 를 혼합하여 약 2 분간 $10000 \mathrm{rpm}$ 에서 homogenizer(AM-7, ace homogenizer, Nihonseiki, Japan)로 균질화 한 다 음 $\mathrm{pH}$ meter(HM-30V, Toa, Japan)로 측정하였다.

\section{7. 통계처리}

실험결과는 3 차례의 평균값을 구하여 mean \pm 
$\mathrm{SD}$ 로 나타내었으며, 각 군에 따른 유의차 검 증은 분산분석을 한 후 $a=0.05$ 수준에서 Duncan's multiple test(SAS Institute, 1988)에 따 라 분석하였다.

\section{III 결과 및 고찰}

\section{1. 양념돈육의 저장성}

분자량 약 $120 \mathrm{kDa}$ 의 키토산을 $0.05 \sim 1.00 \%$ 의 농도로 수용액을 제조하여 양념돈육에 첨 가한 다음 $4{ }^{\circ} \mathrm{C}$ 에서 10 일간 저장하면서 저장 효과를 알아보기 위해 생균수를 측정하였다. 그 결과 전체적으로 생균수는 저장기간이 경 과함에 따라 증가하였다(Fig. 1). 그러나 키토 산을 첨가한 것은 첨가하지 않은 것에 비해 생균수가 적은 것으로 나타났다. 또한 저장 10 일째 키토산 농도 $0.10 \%, 0.50 \%, 1.00 \%$ 에 서는 저장성이 상당히 유지되어 처리하지 않 은 것의 경우 $10^{7}$ 이상인 것에 비해 $10^{5}$ 정도 로 나타났다. 따라서 키토산의 첨가량이 증가 할수록 양념돈육의 저장성도 향상되었으며, 특히 키토산을 $0.10 \%$ 이상 첨가할 경우 저장 성에 상당한 효과가 있는 것으로 나타났다. 이는 소시지(Youn 등, 1999)와 식빵(Lee 등, 2002)에 키토산을 첨가했을 때와 같은 결과를 보여주고 있다.

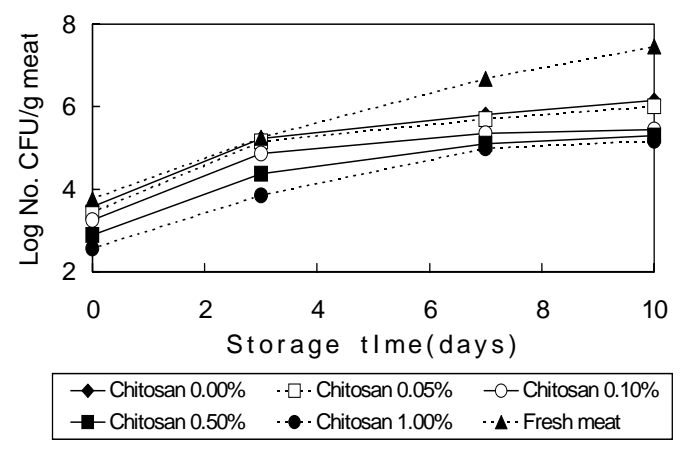

Fig. 1. Changes in total bacterial cell count on vacuum-packaged seasoned pork meat by added various concentration of M.W. $120 \mathrm{kDa}$ chitosan during storage at $4^{\circ} \mathrm{C}$

\section{2. 지질의 산화도}

지방산화가 진행되면 malonaldehyde, acetal 화 합물 등이 증가하는데 이에 2-thiobarbituric acid 를 반응시켜, 발색된 색의 정도로부터 이들의 유리화합물, 즉 산화의 촉진 정도를 측정하고 있다(Melton, 1983). Fig. 2는 저장기간에 따른 양념돈육의 지질 산화도를 TBARS으로 나타낸 것으로 양념돈육에 키토산을 첨가하고 진공 포 장하여 $4{ }^{\circ} \mathrm{C}$ 에서 10 일간 저장하면서 경시적으 로 TBARS의 함량을 측정하여 나타냈다. 그 결과 전체적으로 저장기간이 경과함에 따라 TBARS의 함량은 증가하였다. 이는 저장기간이 경과함에 따라 지질의 산화도가 증가한다는 보 고들(Witte 등, 1970; Park 등, 1988; Park 등, 1988; Park 등, 1994)과 일치하는 것이다. 또한 키토산 용액을 첨가한 경우는 첨가하지 않은 것 에 비해 TBARS의 함량이 대체로 낮았다. 그리 고, 키토산의 첨가 농도가 증가할수록 TBARS의 함량은 낮게 측정되었다. 특히 키토산의 첨가 농도가 $1.0 \%$ 일 경우 저장 10 일째 TBARS 함량 이 0.358 인데 비해 무첨가구는 0.4110 으로 산화 억제 효과가 뚜렷한 것으로 나타났는데, 이는 키토산 자체가 항산화 효과를 타나낸다는 Xue 등(1998)의 결과를 토대로 키토산을 소시지에 첨가하였을 경우 첨가농도가 증가할수록 항산 화 효과가 크다는 Youn 등(2001)의 결과와 일 치하였다.



Fig. 2. Changes of TBARS value on vacuum-packaged seasoned pork meat by added various concentration of M.W. $120 \mathrm{kDa}$ chitosan during storage at $4^{\circ} \mathrm{C}$ 


\section{3. $\mathrm{pH}$ 의 변화}

분자량 약 $120 \mathrm{kDa}$ 의 키토산을 첨가한 양념 돈육의 $\mathrm{pH}$ 변화를 측정한 결과 저장 초기 양념 돈육의 $\mathrm{pH}$ 는 $5.59 \sim 6.18$ 로 나타났는데(Fig. 3), 저장 10 일에는 $5.52 \sim 6.09$ 로 나타났으나 저장기 간에 따른 차이는 없는 것으로 나타났다. Lee (1989)는 돈육을 염지한 후 저장 24시간 후의 $\mathrm{pH}$ 가 $5.87 \sim 5.92$ 였던 것이 7일 후에 $5.86 \sim 6.09$ 로써 큰 변화가 없었고, $\mathrm{Kim}$ 등(2002)도 여러 가지 포장방법에 의해 포장된 양념갈비의 $\mathrm{pH}$ 가 저장기간에 따른 차이가 없다고 보고하였다. 또 한 결과에서 분자량 약 $120 \mathrm{kDa}$ 의 키토산을 농도별로 첨가한 경우 그 첨가농도가 증가할 수록 $\mathrm{pH}$ 는 낮게 나타났다. 이는 키토산 용액

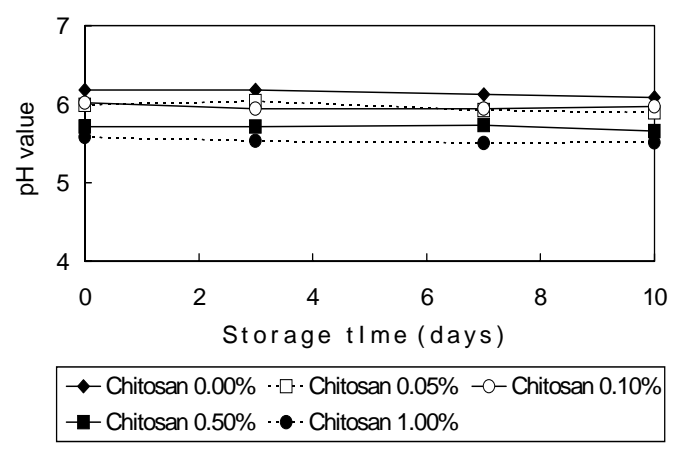

Fig. 3. Changes of $\mathrm{pH}$ value on vacuumpackaged seasoned pork meat by added various concentration of M.W. $120 \mathrm{kDa}$ chitosan during storage at $4^{\circ} \mathrm{C}$
자체의 $\mathrm{pH}$ 가 5.5이기 때문에 첨가하지 않은 것 에 비해 $\mathrm{pH}$ 가 낮게 나타나 첨가량이 많아질수 록 낮은 $\mathrm{pH}$ 를 유지하였다. 본 실험에서 키토산 용액의 제조시 $\mathrm{pH}$ 를 5.5로 조절한 이유는 도살 후 원료 돈육의 최저 $\mathrm{pH}$ 와 비슷하며, $\mathrm{pH} 5.0$ 이하에서는 육단백질이 변성되고(Park 등, 2003), $\mathrm{pH} 6.0$ 이상에서는 키토산의 용해도가 떨어지 기 때문이다.

\section{4. 색의 변화}

키토산을 농도별로 제조하여 양념돈육에 첨 가하여 저장기간 동안의 색도를 측정하였다 (Table 2). 그 결과, 저장 초기에는 원료육에 비 해 양념한 것이 명도, 적색도, 황색도가 크게 떨어졌다. 키토산을 첨가한 양념돈육은 첨가하 지 않은 양념돈육에 비해 저장 초기의 명도 $\left(\mathrm{L}^{*}\right)$ 가 높은 것으로 나타났다. 그리고 적색도 $\left(\mathrm{a}^{*}\right)$ 는 키토산을 첨가하지 않은 양념돈육에 비해 키토 산을 첨가한 구가 높게 나타났으며, 특히 $1.0 \%$ 첨가구에서 1.16 으로 높게 나타났다. 황색도 $\left(\mathrm{b}^{*}\right)$ 또한 키토산을 첨가한 구에서 높은 수치를 나 타냈다. 10 일간 저장 후에는 원료육의 명도, 적 색도도 저하하였으나 황색도는 특히 현저히 낮 아졌다. 키토산을 처리한 양념육은 처리하지 않은 것에 비해 명도, 적색도가 높게 유지되었 는데 특히 $0.5 \%$ 이상 첨가구에서 더욱 안정되 게 유지되었다. 또한 황색도는 저장 전에 비해 $0.05 \%$ 첨가구에서는 낮았으나 그 이상의 첨가

Table 2. Changes of color on vacuum-packaged seasoned pork meat by added various con centration of chitosan during storage at $4{ }^{\circ} \mathrm{C}$

\begin{tabular}{|c|c|c|c|c|c|c|}
\hline Storage time & & 0 day & & & 10 day & \\
\hline Sample & $\mathrm{L}^{*}$ & $a^{*}$ & $b^{*}$ & $\mathrm{~L}^{*}$ & $a^{*}$ & $\mathrm{~b}^{*}$ \\
\hline Fresh meat & $62.93 \pm 0.02^{\mathrm{aA}}$ & $3.87 \pm 0.04^{\mathrm{aA}}$ & $48.79 \pm 0.10^{\mathrm{aA}}$ & $61.38 \pm 0.03^{\mathrm{aB}}$ & $3.44 \pm 0.03^{\mathrm{aB}}$ & $12.72 \pm 0.03^{\mathrm{eB}}$ \\
\hline Chitosan $0.00 \%$ & $57.36 \pm 0.10^{\mathrm{eA}}$ & $-0.88 \pm 0.12^{\mathrm{dA}}$ & $13.87 \pm 0.04^{\mathrm{dA}}$ & $55.46 \pm 0.02^{\mathrm{fB}}$ & $-0.73 \pm 0.12^{\mathrm{cA}}$ & $13.96 \pm 0.05^{\mathrm{dA}}$ \\
\hline Chitosan $0.05 \%$ & $59.07 \pm 0.13^{\mathrm{CA}}$ & $0.68 \pm 0.10^{\mathrm{cA}}$ & $15.44 \pm 0.06^{\mathrm{bA}}$ & $57.08 \pm 0.01^{\mathrm{eB}}$ & $0.06 \pm 0.13^{\mathrm{cB}}$ & $15.31 \pm 0.07^{\mathrm{CA}}$ \\
\hline Chitosan $0.10 \%$ & $58.73 \pm 0.04^{\mathrm{dA}}$ & $0.49 \pm 0.07^{\mathrm{cA}}$ & $14.85 \pm 0.03^{\mathrm{cB}}$ & $57.50 \pm 0.00^{\mathrm{dB}}$ & $0.14 \pm 0.05^{\mathrm{cB}}$ & $15.57 \pm 0.01^{\mathrm{bA}}$ \\
\hline Chitosan $0.50 \%$ & $59.04 \pm 0.05^{\mathrm{cA}}$ & $0.57 \pm 0.08^{\mathrm{cA}}$ & $15.06 \pm 0.06^{\mathrm{CB}}$ & $58.46 \pm 0.05^{\mathrm{cB}}$ & $0.63 \pm 0.07^{\mathrm{bA}}$ & $16.37 \pm 0.03^{\mathrm{aA}}$ \\
\hline Chitosan $1.00 \%$ & $59.52 \pm 0.03^{\mathrm{bA}}$ & $1.16 \pm 0.10^{\mathrm{bA}}$ & $15.4 \pm 0.07^{\mathrm{bB}}$ & $58.69 \pm 0.04^{\mathrm{bB}}$ & $0.81 \pm 0.08^{\mathrm{bB}}$ & $16.50 \pm 0.06^{\mathrm{aA}}$ \\
\hline
\end{tabular}


Table 3. Changes of water holding capacity on vacuum-packaged seasoned pork meat by added various concentration of chitosan during storage at $4{ }^{\circ} \mathrm{C}$

\begin{tabular}{lcccc}
\hline \multirow{2}{*}{ Sample } & \multicolumn{4}{c}{ Days } \\
\cline { 2 - 5 } & 0 & 3 & 7 & 10 \\
\hline \hline Fresh meat & $94.53 \pm 0.00^{\mathrm{b}}$ & $94.53 \pm 0.00^{\mathrm{b}}$ & $95.56 \pm 0.07^{\mathrm{a}}$ & $94.13 \pm 0.14^{\mathrm{b}}$ \\
Chitosan 0.00\% & $92.15 \pm 0.07^{\mathrm{d}}$ & $92.03 \pm 0.14^{\mathrm{d}}$ & $92.76 \pm 0.47^{\mathrm{C}}$ & $90.89 \pm 0.00^{\mathrm{e}}$ \\
Chitosan 0.05\% & $89.38 \pm 0.53^{\mathrm{ijk}}$ & $90.85 \pm 0.00^{\mathrm{e}}$ & $90.46 \pm 0.14^{\mathrm{ef}}$ & $90.72 \pm 0.13^{\mathrm{e}}$ \\
Chitosan 0.10\% & $89.71 \pm 0.47^{\mathrm{igh}}$ & $89.11 \pm 0.13^{\mathrm{k}}$ & $90.59 \pm 0.00^{\mathrm{e}}$ & $89.65 \pm 0.13^{\mathrm{igjh}}$ \\
Chitosan 0.50\% & $89.31 \pm 0.07^{\mathrm{jjk}}$ & $89.18 \pm 0.34^{\mathrm{jk}}$ & $90.05 \pm 0.13^{\mathrm{fg}}$ & $89.51 \pm 0.27^{\mathrm{jijk}}$ \\
Chitosan $1.00 \%$ & $89.92 \pm 0.68^{\mathrm{gh}}$ & $89.58 \pm 0.34^{\mathrm{ighk}}$ & $89.71 \pm 0.20^{\mathrm{igh}}$ & $89.38 \pm 0.14^{\mathrm{ijk}}$ \\
\hline
\end{tabular}

${ }^{\mathrm{a}-\mathrm{k}}$ Means in the same column bearing different superscript are singificantly different $(\mathrm{p}<0.05)$.

구에서는 높아졌다. 이러한 결과는 소시지에 키 토산을 첨가한 경우(Youn 등, 2000) 및 우육양 념육의 결과(Youn 등, 2004)와도 대체로 일치한 다. 따라서 양념육에 있어서의 문제점인 육색의 큰 변화, 특히 적색도의 저하 현상을 키토산의 첨가로써 억제하여 양념돈육의 색을 유지할 수 있어 품질 유지에 기여할 것으로 사료된다.

\section{5. 보수력의 변화}

키토산을 첨가한 양념돈육의 경우 보수력이 약간 떨어졌다(Table 3). 이는 키토산 첨가 시 $\mathrm{pH}$ 가 저하하는데서 유래하는 것으로 생각된다. 키토산을 전혀 첨가하지 않은 양념돈육의 보 수력은 저장 7일 째까지 비교적 유지되었으나 저장 10 일 째 감소하는 것으로 나타났다. 그러 나 키토산을 첨가한 양념돈육은 저장 10 일까지 안정한 것으로 나타났다. 식육을 저장할 경우, 단백질 변성에 의해 보수력이 저하하게 되는데 그 결과 다즙성 및 물성 측면에서 소비자들의 기호도를 저하시키는 주요 원인이 되며, 동시에 미생물의 오염을 촉진시킬 수 있다(Kauffman 등, 1986). 본 연구결과 키토산을 양념돈육에 첨 가했을 경우 저장 초기에 약간 보수력이 떨어지 나 저장 중 보수력을 유지하게 되어 품질유지에 큰 영향을 미치지 않을 것으로 사료된다.

$$
\text { IV 요 약 }
$$

본 연구는 양념돈육에 분자량 약 $120 \mathrm{kDa}$ 의
키토산을 0.05 에서 $1.0 \%$ 까지 첨가하여, 양념돈 육의 보존성 및 품질에 미치는 영향에 대해 알 아보기 위하여 생균수, 지질 산화도, $\mathrm{pH}$, 색도와 보수력을 측정하였다. 저장기간이 경과함에 따 라 양념돈육의 생균수는 증가하였으나, 키토산 을 첨가한 양념돈육은 첨가하지 않은 것에 비해 생균수가 효과적으로 억제되었으며, 키토산을 $0.10 \% .0 .50 \%, 1.00 \%$ 비율로 첨가했을 때는 저 장 10 일 동안 저장성이 상당히 유지되었다. 또 한 키토산의 첨가량이 증가함에 따라 저장성도 향상되었다. 키토산을 첨가하지 않은 양념돈육 은 저장기간이 경과함에 따라 TBARS의 함량이 점차 증가하였으며, 키토산을 첨가한 경우는 첨 가하지 않은 것에 비해 TBARS의 함량이 대체 로 낮게 나타나 지질 산화를 억제하는 것으로 나타났다. 또한 키토산의 첨가 농도가 증가할수 록 지질산화 억제효과가 큰 것으로 나타났다. 양념돈육의 $\mathrm{pH}$ 변화를 측정한 결과 키토산을 첨가한 것이 $\mathrm{pH}$ 가 낮았으나 저장기간 동안 거 의 일정하게 유지되었다. 저장기간에 따른 양념 돈육의 색의 변화를 살펴보면 키토산을 첨가한 구의 명도 $\left(\mathrm{L}^{*}\right)$, 적색도 $\left(\mathrm{a}^{*}\right)$, 황색도 $\left(\mathrm{b}^{*}\right)$ 가 키토산을 첨가하지 않은 것에 비해 모두 높은 수치를 나 타냈다. 보수력은 키토산을 첨가한 양념돈육에 있어 초기에는 낮았으나 저장 10 일까지 보수력 이 비교적 안정한 것으로 나타났다.

$$
\mathrm{V} \text { 사 사 }
$$

이 논문은 2003년도 Brain Busan 21사업에 
의하여 지원되었기에 이에 감사드립니다.

\section{$\mathrm{VI}$ 인 용 문 헌}

1. Chen, C. S., Lian, W. Y. and Tsai, G. J. 1998. Antibacterial effect of $\mathrm{N}$-sulfonated and N-sulfobenzoyl chitosan and application to oyster preservation. J. Food Prot. 61:1124-1128.

2. Cho, S. H., Park, B. Y., Yoo, Y. M., Chae, H. S., Wyi, J. J., Ahn, C. N., Kim, J. H., Lee, J. M., Kim, Y. K. and Yun, S. G. 2002. Physico-chemical and sensory characteristics of pork bulgogi containing ginseng saponin. Korean J. Food Sci. Ani. Resour. 22:30-36.

3. Choi, W. S. and Lee, K. T. 2002. Quality changes and shelf-life of seasoned pork with soy sauce of kochujang during chilled storage. Korean J. Food Sci. Ani. Resour. 22:240-246.

4. Chun, K. H., Kim, B. Y., Son, T. I. and Hahm, Y. T. 1997. The extension of tofu shelf-life with water-soluble degraded chitosan as immersion solution. Korean J. Food Sci. Technol. 29:476-481.

5. Donald, W. W. and Mirocha, C. J. 1977. Chitin as a measure of fugal growth in stored corn and soybean seed. J. Food Technol. 12:581-584.

6. Goosen, MFA. 1997. Applications of chitin and chitosan. Technomic Publishing, Lancaster, USA. p. 320.

7. Hadwiger, L. A., Fridtensky, B. and Riggleman, R. C. 1984. Chitosan, a natural regulator in plant-fungal pathogenic interactions, increases crop yeilds. In Chitin, Chitosan and Related Enzymes. Academic Press, New York, 291-302.

8. Hur, E. Y., Lee, M. H. and No, H. K. 1997. Verigication of conventional kimchi preservation methods. J. Korean Soc. Food Sci. Nutr. 26:807813.

9. Kauffman, R. G., Eikelenboom, G., Vander Wal, P. G., Engel, B. and Zaar, M. 1986. A comparison of methods to estimate water holding capacity in post-rigor porcine muscle. Meat Sci., 18:307-322.

10. Kim, C. J., Jeong, J. Y., Lee, E. S. and Song, H. H. 2002. Studies on improvement of quality and shelf-life of traditional marinated beef(Galbi) as affected by packaging method during storage at $-1{ }^{\circ} \mathrm{C}$. Korea J. Food Sci. Technol. 34:792-798.

11. Kim, K. O., Moon, H. A. and Jeon, D. W. 1995. The effect of low molecular weight chitosans on the characteristics of kimchi during fermentation.
Korean J. Food Sci. Technol. 27:420-427.

12. Lee, H. K. 1989. Effect of sodium nitrite level and curing temperature on physico-chemical characteristics of cured pork meat. Ph.D. disseration, Sangji Univ., Korea

13. Lee, H. Y., Kim, S. M., Kim, J. Y., Youn, S. K., Choi, J. S., Park, S. M. and Ahn, D. H. 2002. Effect of addition of chitosan on improvement for shelf life of bread. J. Korean Soc. Food Sci. Nutr. 31:445-450.

14. Lee, S. H., No, H. K. and Joung, Y. H. 1996. Effect of chitosan coating on quality of egg during storage. J. Korean Soc. Food Sci. Nutr. 25:288293.

15. Melton, S. L. 1983. Methodology following lipid oxidation in muscle food. Food Technol. 37:105108.

16. Moon, J. H., Ryu, H. S. and Lee, K. H. 1991. Effect of garlic on the digestion of beef protein during storage. J. Korean Soc. Food Sci. Nutr. 20: 447-454.

17. No, H. K., Park, I. K. and Kim, S. D. 1995. Extension of shelf-life of kimchi by addition of chitosan during salting. J. Korean Soc. Food Nutr., 24:11-15.

18. Official Book for Food. KFDA. 2002.

19. Official Book for Food. KFDA. 2003.

20. Oh, D. H. 1986. Studies on the quality of cured meat in the processing. Ph.D. dissertation, Chonbuk National Univ., Korea.

21. Park, G. B., Kang, S. H., Kim, Y. J., Lee, H. G. and Kim, Y. H. 2003. Change in meat protein of korean native goats meat during postmortem storage. Korean J. Food Sci. Ani. Resour. 23:1-8.

22. Park, G. B., Kim, Y. J., Lee, H. G., Kim, J. S. and Kim, Y. H. 1988. Changes in freshness of meats during postmortem storage. I. Change in freshness of prok. Korean J. Anim. Sci. 30:561566.

23. Park, G. B., Kim, Y. J., Lee, H. G., Kim, J. S. and Kim, Y. H. 1988. Changes in freshness of meats during postmortem storage. II. Change in freshness of beef. Korean J. Anim. Sci. 30:671672.

24. Park, G. B., Lee, H. G., Kim, J. S., Kim, Y. J., Park, T. S., Shin, T. S., and Lee, J. I. 1994. Effect of sodium nitrite levels and curing temperatures on preservation and production of antihygenic chemicals of cured pork. Korean J. Anim. Sci. 36:330-339. 
25. SAS Institute. 1988. SAS/STATTM user's guide, release 6.03 ed. SAS Institute Inc., Cary, N. C.

26. Simpson, B. K., Gagne, N., Ashie, I. N. A. and Noroozi, E. 1997. Utilization of chitosan for preservation of raw shrimp. Food Biotechnol. 11:25-44.

27. Skjak B., Anthonsen T. and Sandford P. 1989. Chitin and chitosan. Elsevier Applied Science, London. p. 560.

28. Son, Y. M., Kim, K. O., Jeon, D. W. and Kyung, K. H. 1996. The effect of low molecular weight chitosan with and without other preservatives on the characteristics of kimchi during fermentation. Korean J. Food Sci. Technol. 28:888-896.

29. Statistical yearbook of agricultural and forestry industries. MAF. 2001. Wierbick, E., Kunkle, L. E. and Deatherage, F. E. 1975. Changes in water holding capacity of cationic shifts during the heating, freezing and thawing of meat as revealed by a simple centrifugal method for measuring shrinkage. J. Food Tech. 11: p. 69.

30. Witte, V. C., Krause, G. F. and Bailey, M. E. 1970. New extraction method for determining 2thiobarbituric acid values of pork and beef during storage. J. Food Sci. 35:582-585.
31. Xue, C., Yu, G., Hirata, T., Terao, J. and Lin, H. 1998. Antioxidative activities of several marine polysaccharides evaluated in a phosphatidylcholine-liposomal suspension and organic solvents. Biosci. Biotechnol. Biochem. 62:206-209.

32. Youn, S. K., Her, J. H., Kim, Y. J., Choi, J. S., Park, S. M. and Ahn, D. H. 2004. Studies on the improvement of shelf-life in spicy beef meat using chitosan. J. Korean Soc. Food Sci. Nutr. 23:207211.

33. Youn, S. K., Kim, Y. J. and Ahn, D. H. 2001. Antioxidative effects of chitosan in meat sausage. J. Korean Soc. Food Sci. Nutr. 30:477-481.

34. Youn, S. K., Park, S. M. and Ahn, D. H. 2000. Studies on the improvement of storage property in meat sausage using chitosan- $\amalg$. J. Korean Soc. Food Sci. Nutr. 29:849-853.

35. Youn, S. K., Park, S. M., Kim Y. J. and Ahn, D. H. 1999. Effect on storage property and quality in meat sausage by added chitosan. J. Chitin Chitosan 4:189-195.

36. Yun, Y. S., Kim, K. S. and Lee, Y. N. 1999. Antibacterial and antifungal effect of chitosan. J. Chitin Chitosan 4:8-14.

(접수일자 : 2004. 10. 28. / 채택일자 : 2004. 12. 6.) 